\title{
Demonstration of the Production and Physiological Role of Insulin-like Growth Factor II in Rat Thyroid Follicular Cells in Culture
}

\author{
Rui M. B. Maciel, * Alan C. Moses, * Giovanni Villone, ${ }^{\ddagger}$ Donatella Tramontano, ${ }^{5}$ and Sidney H. Ingbar* \\ ${ }^{*}$ Charles A. Dana Research Institute and the Harvard-Thorndike Laboratory, Department of Medicine, Beth Israel Hospital and \\ Harvard Medical School, Boston, Massachusetts 02115; ${ }^{\ddagger}$ Centro di Endocrinologia e Oncologia Sperimentale del CNR, Naples, Italy; \\ ${ }^{\S}$ Istituto di Oncologia Sperimentale e Clinica, Facolta di Medicina e Chirurgia di Catanzaro, Catanzaro, Italy
}

\begin{abstract}
Insulin-like growth factors (IGFs) are potent mitogens for FRTL5 rat thyroid follicular cells. IGFs also synergize the independent mitogenic effects of thyrotropin-stimulating hormone (TSH) and other agents that increase intracellular AMP concentration.

We examined whether FRTL5 cells and M12 cells, a TSH-independent mutant cell line derived therefrom, secrete IGF that regulates the growth of rat thyroid follicular cells. Immunoreactive IGF-II, but not IGF-I, was found in media conditioned by FRTL5 cells; media from M12 cells contained four- to fivefold higher concentrations. Medium conditioned by FRTL5 and M12 both stimulated $\left[{ }^{3} \mathrm{H}\right]$ thymidine incorporation in FRTL5 and amplified the mitogenic effects of TSH. M12conditioned medium was more potent than FRTL5-conditioned medium.

Sm-1.2, a monoclonal antibody that recognizes IGF-I and IGF-II but not insulin, inhibited basal DNA synthesis in FRTL5 and M12 cells and the mitogenic effects in FRTL5 of agents that are synergized by IGF, such as TSH, forskolin, $\mathrm{Bt}_{2} \mathrm{cAMP}$, and Graves'-IgG. Sm-1.2 did not inhibit the mitogenic response to insulin. Thus, rat insulin-like growth factor II (rIGF-II) is an autocrine growth factor that regulates FRTL5 growth, in part by amplifying the mitogenic response to TSH. Results with M12 cells raise the possibility that endogenous rIGF-II may partially mediate the TSH-independent growth of these cells.
\end{abstract}

\section{Introduction}

In recent years, regulation of thyroid cell growth has become a topic of interest in numerous laboratories, including our own (1-9). In pursuing this topic, we, like others, have employed as a model the FRTL5 line of rat thyroid follicular cells. Although capable of being maintained in continuous culture, FRTL5 cells do not display other characteristics of transformed cells, and after many years in culture, they retain many of the differentiated functions of the thyroid follicular cell in vivo (1). Although the growth of FRTL5 cells has been thought to be almost entirely dependent upon the presence of thyrotro-

Address reprint requests to Dr. Alan C. Moses, Charles A. Dana Research Institute, Department of Medicine, Beth Israel Hospital, 330 Brookline Ave., Boston, MA 02115.

Received for publication 2 November 1987 and in revised form 27 May 1988.

\footnotetext{
J. Clin. Invest.

(c) The American Society for Clinical Investigation, Inc.

$0021-9738 / 88 / 11 / 1546 / 08 \quad \$ 2.00$

Volume 82, November 1988, 1546-1553
}

pin-stimulating hormone (TSH), other agents that increase effective levels of intracellular cAMP, as TSH does, also stimulate DNA synthesis $(5,6,9)$. Moreover, recombinant insulinlike growth factor I (IGF-I), ${ }^{1}$ which does not increase intracellular cAMP concentration in FRTL5 cells (9), nonetheless has an independent action to increase DNA synthesis and replication in these cells and, most importantly, synergizes the effect of TSH to increase DNA synthesis (8).

In examining the characteristics of the interactions between IGF-I and the cAMP-mediated growth pathway, we conducted studies of the effects of sm-1.2, a monoclonal antiIGF antibody. Effects of this antibody on the growth of FRTL5 cells and their responses to various mitogens raised the strong possibility that these cells produce an immunoreactive IGF. We therefore performed experiments to examine this question directly and, in so doing, obtained evidence that the cells do indeed produce rat IGF-II (rIGF-II). This, in turn, led us to additional studies of the functional significance of the endogenous IGF. The evidence that FRTL5 cells produce rIGF-II, that this endogenous IGF-II acts as an autocrine growth factor, and that it also conditions the response to other mitogens constitutes the substance of this report. A portion of these results has been presented in abstract form (10).

\section{Methods}

Special reagents. Monoclonal antibody to IGF-I (sm-1.2) was generously provided by Dr. Judson J. Van Wyk (University of North Carolina, Chapel Hill, NC). This antibody cross-reacts with human IGF-II (hIGF-II) and rIGF-II (MSA-III-2) to the extent of $\sim 5$ and $1 \%$, respectively, but does not cross-react with insulin (11), a finding confirmed in our laboratory. Polyclonal antiserum to human IGF-I (hIGF-I) for use in RIAs was kindly provided by Dr. Richard W. Furlanetto (University of Pennsylvania, Philadelphia, PA). This antiserum reacts with the IGF-I of many species, including that of the rat. It is highly specific for IGF-I, having $<5 \%$ cross-reactivity with hIGF-II or rIGF-II $(12,13)$. The polyclonal antibody to rIGF-II used for RIAs cross-reacts with IGF-I and hIGF-II to the extent of $\sim 3$ and $10 \%$, respectively, but does not cross-react with insulin (14). rIGF-II $(7,100 \mathrm{~mol} \mathrm{wt})$ purified from culture medium conditioned by the BRL-3A line of rat liver cells was a gift from Dr. S. Peter Nissley (National Institutes of Health, Bethesda, MD) (15). hIGF-II, purified from outdated human plasma, was a gift from Dr. Rene Humbel (Zurich, Switzerland) (16). Purified bovine thyrotropin (bTSH, $30 \mathrm{IU} / \mathrm{mg}$ ) was kindly provided by the National Hormone and Pituitary Program (National Institute of Diabetes and Digestive and Kidney Disease, Bethesda, MD). Recombinant hIGF-I used for radioiodination was kindly supplied by Creative Biomolecules (Hopkinton, MA), and PP-12, a highly purified IGF-I binding protein, by Dr. H. Bohn (Behringswerke, Marburg, FRG).

1. Abbreviations used in this paper: bTSH, bovine thyrotropin; hIGF, human insulin-like growth factors; IGF, insulin-like growth factors; rIGF, rat insulin-like growth factors. 
Other materials. The remaining materials were purchased from commercial sources, as follows: Coon's modified Ham's F-12 tissue culture medium from Hazleton-KC Laboratories (Kansas City, KS); calf serum, DME, penicillin-streptomycin solution, and RPMI 1640 from Gibco Laboratories (Grand Island, NY); transferrin, bovine insulin, partially purified bTSH used in the maintenance of cell cultures, dibutyryl cAMP ( $\left.\mathrm{Bt}_{2} \mathrm{CAMP}\right)$, methylisobutylxanthine, and SDS from Sigma Chemical Co. (St. Louis, MO); fraction V of BSA, forskolin, and goat anti-rabbit gamma globulin from Calbiochem (La Jolla, CA); Sephadex G-50 from Pharmacia Fine Chemicals (Piscataway, NJ); tissue culture dishes ( 24 wells; 16 or $75 \mathrm{~mm}^{2}$ ) and flasks $(250 \mathrm{ml})$ from Costar (Cambridge, MA); tissue culture dishes $(35 \times 10 \mathrm{~mm}$ and 100 $\times 20 \mathrm{~mm}$ ) from Falcon Plastics (Cockeysville, MD); recombinant IGF-I (Thr ${ }^{59}$-IGF-I) from Amgen Biologicals (Thousand Oaks, CA); trypsin 1-300 from ICN Nutritional Biochemicals (Cleveland, $\mathrm{OH}$ ); normal mouse serum from Miles Laboratories Inc. (Elkhart, IN); cholera toxin from List Biological Laboratories, Inc. (Campbell, CA); [methyl- ${ }^{3} \mathrm{H}$ ]thymidine $(6.5 \mathrm{mCi} / \mathrm{mmol})$ and carrier-free $\mathrm{Na}^{125} \mathrm{I}$ from DuPont New England Nuclear Research Products (Boston, MA); SepPak C-18 cartridges from Waters Associates (Milford, MA). Kits for the RIA of cAMP were purchased from ImmunoNuclear (Stillwater, $\mathrm{MN}$ ). All other chemicals were of reagent or higher grade.

Culture techniques. FRTL5 cells were routinely cultured in Coon's modified Ham's F-12 medium supplemented with $5 \%$ calf serum and three "hormones": bTSH $(1 \mathrm{mU} / \mathrm{ml})$, insulin $(1 \mu \mathrm{g} / \mathrm{ml})$, and transferrin $(5 \mu \mathrm{g} / \mathrm{ml})(3 \mathrm{H}$ medium). Cells were cultured in $250-\mathrm{ml}$ flasks or 24-well plates at $37^{\circ} \mathrm{C}$ in an atmosphere of $95 \%$ air-5\% $\mathrm{CO}_{2}$ in a humidified incubator as described previously (1).

Some experiments were performed with M12 cells, a clone of mutant cells derived from FRTL5 cells that grow in the absence of TSH (17). These cells were grown in the same medium as FRTL5 cells, except that bTSH, insulin, and transferrin were omitted ( $\mathrm{H}$-free medium).

Preparation of conditioned media for immunoassay. Subconfluent cultures of FRTL5 cells or M12 cells in 100-mm dishes were washed several times with Coon's modified Ham F-12 medium supplemented with $0.1 \%$ BSA. FRTL5 cells were then cultured in the same medium supplemented with insulin $(1 \mu \mathrm{g} / \mathrm{ml})$, transferrin $(5 \mu \mathrm{g} / \mathrm{ml})$, and bTSH $(1 \mathrm{mU} / \mathrm{ml})$. M12 cells were cultured in the same medium, except that bTSH was omitted. After $48 \mathrm{~h}$ of culture, medium from four dishes was pooled and centrifuged. The clear supernatant was acidified with acetic acid (final concentration, $1 \mathrm{M}$ ), dialyzed extensively against $1 \mathrm{M}$ acetic acid, and lyophilized. Comparable media were incubated in the absence of cells for use as controls.

Lyophilized conditioned media were resuspended in $1 \mathrm{M}$ acetic acid to dissociate IGFs from their binding proteins (18). IGFs were then resolved from their binding proteins by one of two different techniques. The first involved chromatography on a $2 \times 50 \mathrm{~cm}$ Sephadex G-50 column in $1 \mathrm{M}$ acetic acid (18), a procedure that separates the low molecular weight IGFs from their binding proteins. The column had previously been calibrated with ${ }^{125} \mathrm{I}-\mathrm{IGF}-\mathrm{I}$ or ${ }^{125} \mathrm{I}$-rIGF-II and ${ }^{125} \mathrm{I}-$ PP-12 (19). Fractions corresponding to the inclusion volume of IGF-I and -II were pooled and lyophilized.

In the second procedure, we used a manual reverse phase technique previously adapted by Hsu and Hammond (20) to isolate IGFs and to separate them from IGF binding proteins. Sep-Pak C-18 cartridges were washed with $5 \mathrm{ml}$ isopropyl alcohol, $5 \mathrm{ml}$ methanol, and $10 \mathrm{ml} 4 \%$ acetic acid. The lyophilized conditioned media were resuspended in $0.5 \mathrm{ml}$ of $1 \mathrm{M}$ acetic acid and applied to the cartridge; this was then washed with $10 \mathrm{ml}$ of $4 \%$ acetic acid to remove any residual IGF-I binding protein. IGFs were then eluted from the column with $5 \mathrm{ml}$ of methanol and the samples were lyophilized.

RIAs of IGF-I and rIGF-II. Recombinant hIGF-I and native rIGF-II were labeled with ${ }^{125}$ I by methods described previously (21). Samples for analysis prepared either by G- 50 or by Sep-Pak chromatography were redissolved in assay buffer for analysis, the quantity added to each assay tube being equivalent to $4 \mathrm{ml}$ of original unconcentrated medium. For assay of IGF-I, we used a technique previously described, with minor modifications (22). hIGF-I was used as the radioligand and $\mathrm{Thr}^{59}$-IGF-I as a standard (21). The antibody against IGF-I was employed in a final dilution of $1: 20,000$ and the separation method was precipitation with goat anti-rabbit gamma globulin in the presence of $6 \%$ polyethylene glycol. The sensitivity of the assay was 0.1 ng/tube. rIGF-II was assayed by the method of Moses et al. (14). The antiserum was used in a final dilution of 1:1,000, and the assay sensitivity was $1 \mathrm{ng} /$ tube.

$\left[{ }^{3} \mathrm{H}\right]$ Thymidine incorporation. Studies of $\left[{ }^{3} \mathrm{H}\right]$ thymidine incorporation into DNA were performed as described previously (9). FRTL5 cells were studied 5-7 d after plating into $\mathrm{H}$-free medium, while M12 cells were studied 2-3 d after plating. Data were expressed as counts per minute/well for triplicate determinations.

Biological activity of conditioned media. Subconfluent cultures of FRTL5 cells and M12 cells were washed with Coon's modified Ham's F-12 medium containing $0.1 \%$ BSA and then incubated for $50 \mathrm{~h}$ in the same medium. Media were collected and centrifuged at $500 \mathrm{~g}$, and the clear supernatant was used in varying dilutions, with and without bTSH, as culture medium for quiescent FRTL5 cells in which $\left[{ }^{3} \mathrm{H}\right]-$ thymidine incorporation was measured $48 \mathrm{~h}$ later. Control media had not been conditioned by exposure to cells.

Cell proliferation. FRTL5 cells were seeded into $\mathrm{H}$-free medium containing $5 \%$ calf serum in $60-\mathrm{mm}$ culture dishes and incubated in the same medium for $5 \mathrm{~d}$. Cells then were changed to fresh medium to which the appropriate concentrations of the test agents were added in various combinations. After $5 \mathrm{~d}$ of incubation, cell numbers were determined in a hemocytometer in quadruplicate samples for each experimental condition.

In studies involving the replication of $\mathrm{M} 12$ cells, experimental methods were identical, except that different incubation periods, as indicated, were used.

cAMP accumulation. FRTL5 cells were grown to confluence in $3 \mathrm{H}$ medium in 24-well plates and were then maintained in $\mathrm{H}$-free medium containing $5 \%$ calf serum for $10 \mathrm{~d}$. Monolayers were washed three times with $\mathrm{KRB}, \mathrm{pH} 7.4$, containing $0.1 \%$ glucose, $0.1 \% \mathrm{BSA}$, and 1 $\mathrm{mM}$ methylisobutylxanthine. Cells were then incubated for $30 \mathrm{~min}$ at $37^{\circ} \mathrm{C}$ in $250 \mu \mathrm{l}$ of the same buffer containing the appropriate concentrations of the test agents. Supernatants were then analyzed for cAMP concentration by specific RIA (23).

Binding of ${ }^{125}$ I-bTSH. bTSH was labeled by a gentle chloramine T technique, as previously described (24), to a specific activity of 150 $\mu \mathrm{Ci} / \mu \mathrm{g}$. ${ }^{125} \mathrm{I}$-bTSH binding to confluent FRTL5 cells was performed (9, 23) in a modified $\mathrm{KRB}$ in which $\mathrm{NaCl}$ was replaced by sucrose in sufficient concentration $(280 \mathrm{mM})$ to maintain the tonicity of the solution (modified KRB) as described previously $(9,23)$. Incubations were carried out overnight at $4^{\circ} \mathrm{C}$.

Statistical analyses. All experiments were performed at least three times, with good concordance in the results obtained. Statistical analyses of the results in each experiment were performed by means of analysis of variance followed by the Neuman-Keuls test for multiple sample intercomparisons (25).

\section{Results}

\section{RIA for IGF-I and rIGF-II in conditioned media}

IGF-I could not be detected in concentrates of media conditioned by either FRTL5 cells or M12 cells, as judged from an RIA capable of detecting $0.1 \mathrm{ng}$ IGF-I per tube. Since each assay tube contained the equivalent of $4 \mathrm{ml}$ of original, unconcentrated conditioned medium, each milliliter of the original medium must have contained $<25$ pg IGF-I.

Concentrates of media conditioned by FRTL5 cells or by M12 cells inhibited the binding of ${ }^{125}$ I-rIGF-II to the polyclonal IGF-II antibody, and serial dilutions of media from the two types of cells displayed parallelism with the standard assay curve (Fig. 1). On this basis, it was possible to calculate, for two 


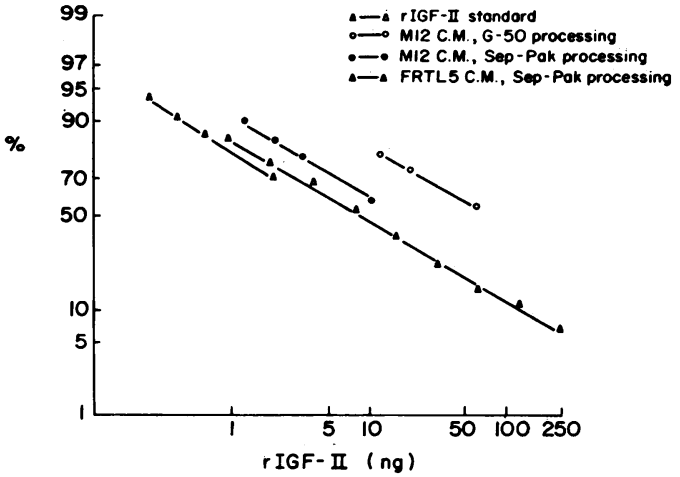

Figure 1. Inhibition of the binding of ${ }^{125}$ I-labeled rIGF-II to a polyclonal anti-rIGF-II antibody by unlabeled rIGF-II and by varying dilutions of culture media conditioned by FRTL 5 cells or by M12 (TSH independent) mutant cells. Data are depicted on a log-logit plot in which the ordinate represents $B / B_{0}$. See text for experimental methods.

separate observations, concentrations of $0.50 \mathrm{ng} / \mathrm{ml}$ and 0.62 $\mathrm{ng} / \mathrm{ml}$ in media conditioned by FRTL 5 cells and $2.25 \mathrm{ng} / \mathrm{ml}$ and $1.50 \mathrm{ng} / \mathrm{ml}$ in media conditioned by the M12 cells. Control media processed in a manner identical to conditioned media did not contain detectable quantities of IGF-I or IGF-II.

\section{Interaction of rIGF-II and TSH}

To facilitate interpretation of many of the results obtained, it became important to determine whether IGF-II would amplify the response of $\left[{ }^{3} \mathrm{H}\right]$ thymidine incorporation in FRTL5 cells to bTSH, as IGF-I had been shown to do (8). Therefore, the ability of IGF II and of insulin in the absence and presence of $10^{-10} \mathrm{M}$ TSH to stimulate $\left[{ }^{3} \mathrm{H}\right]$ thymidine incorporation was examined. At a concentration of $100 \mathrm{ng} / \mathrm{ml}, \mathrm{rIGF}-\mathrm{II}$ induced a slight, but significant $(P<0.001)$, enhancement of $\left[{ }^{3} \mathrm{H}\right]-$ thymidine incorporation into DNA. A moderate stimulation was produced by $10^{-10} \mathrm{M}: \mathrm{TSH}$ alone. When the two were added together, a marked amplification of the individual responses was evident, values for $\left[{ }^{3} \mathrm{H}\right]$ thymidine incorporation being much greater than those that would have been expected from an additive response alone (Fig. 2). At a concentration of $1 \mu \mathrm{g} / \mathrm{ml}$, insulin induced a greater stimulation of $\left[{ }^{3} \mathrm{H}\right]-$ thymidine incorporation than $100 \mathrm{ng} / \mathrm{ml}$ rIGF-II did; nonetheless, the enhancement of the TSH response by insulin was much less marked than that produced by rIGF-II.

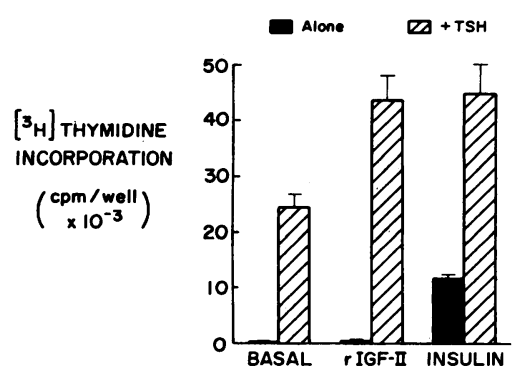

Figure 2. Amplification by rIGF-II and by insulin of the stimulation of $\left[{ }^{3} \mathrm{H}\right]$ thymidine incorporation into the DNA of quiescent FRTL5 cells. Concentrations of the various mitogens used were as follows: bTSH, $10^{-10} \mathrm{M}$, rIGF-II, 100 $\mathrm{ng} / \mathrm{ml}$; insulin, $1 \mu \mathrm{g} /$ $\mathrm{ml}$. Bars represent mean \pm SD of value obtained in triplicate samples.

\section{Effects of conditioned media}

When added alone, media conditioned by FRTL 5 cells or M12 cells, whether studied undiluted or diluted $1: 2$ or $1: 3$ with Coon's modified Ham's F-12 medium containing 0.1\% BSA, slightly increased values of $\left[{ }^{3} \mathrm{H}\right]$ thymidine incorporation by FRTL5 cells. However, they distinctly increased the response to varying concentrations of TSH. Medium conditioned by M12 cells was more potent in its effects than that conditioned by FRTL5 cells (Fig. 3).

\section{Effects of antibody sm-1.2 in FRTL5 cells}

Although the foregoing experiments provided strong evidence that both the FRTL5 cells and the M12 cells secrete IGF-II and condition their media with a factor that influences the growth of quiescent FRTL5 cells as exogenous rIGF-II does, they do not permit an assessment of the role that endogenous IGF-II plays in the growth and mitogenic responses of the cells that produce it. To evaluate these questions, we conducted a number of experiments with sm-1.2, a monoclonal antibody against IGF-I that cross-reacts with IGF-II, but not with insulin.

Responses of basal $\left[{ }^{3} \mathrm{H}\right]$ thymidine incorporation. Data from all experiments involving FRTL5 cells were examined to determine whether sm-1.2 would affect basal thymidine incorporation, i.e., those low levels found in the absence of other additives. In each of $\mathbf{4 3}$ instances, inhibition was produced by the anti-IGF antibody. In these experiments, basal $\left[{ }^{3} \mathrm{H}\right]-$ thymidine incorporation averaged only $365 \pm 192 \mathrm{cpm} / \mathrm{well}$, but it was reduced to an average of $58 \pm 22 \%$ of the respective control values by the addition of $\mathrm{sm}-1.2(10 \mu \mathrm{g} / \mathrm{ml})$.

Responses to IGFs and insulin. In accord with previous observations $(9,10)$, IGF-I $(2.5-20 \mathrm{ng} / \mathrm{ml})$ induced a concentration-dependent stimulation of $\left[{ }^{3} \mathrm{H}\right]$ thymidine incorporation into DNA, and as would be expected, this effect was completely inhibited by the addition of the anti-IGF antibody at a concentration of $5 \mu \mathrm{g} / \mathrm{ml}$ (data not shown).

rIGF-II, hIGF-II, and insulin each stimulated $\left[{ }^{3} \mathrm{H}\right]-$ thymidine incorporation into the DNA of quiescent FRTL5 cells. Responses to rIGF-II and hIGF-II were inhibited in a dose-dependent manner by the antibody sm-1.2 (Fig. 4), but not by equivalent concentrations of normal mouse IgG (data not shown). In contrast, even at the highest concentration

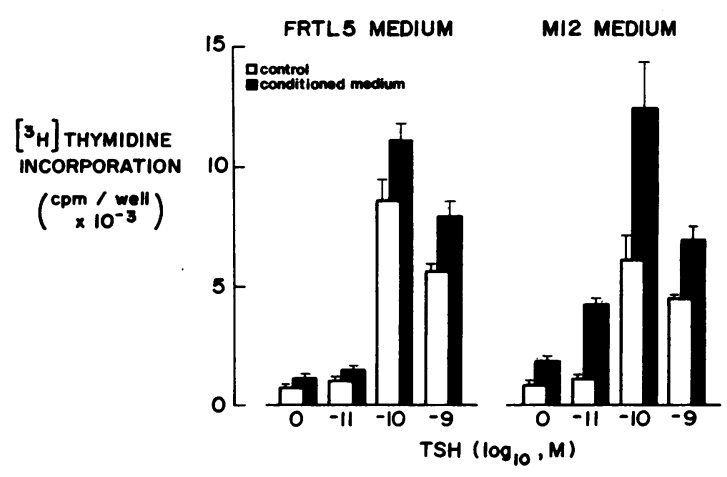

Figure 3. Media conditioned by FRTL5 cells and by M12 cells stimulate $\left[{ }^{3} \mathrm{H}\right]$ thymidine incorporation into DNA in quiescent FRTL5 cells and amplify the increase in thymidine incorporation induced by TSH. Conditioned media were collected after $50 \mathrm{~h}$ of culture and were used at a 1:2 dilution as culture media for quiescent FRTL5 cells. Results shown are the mean $\pm \mathrm{SD}$ of triplicate observations. 


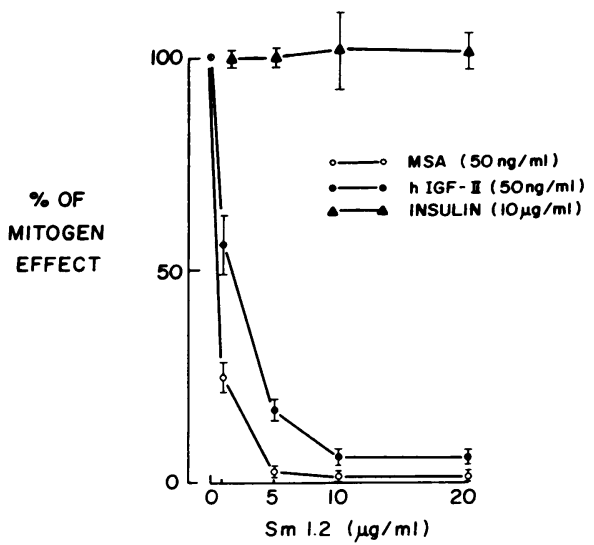

Figure 4. Effects of increasing concentrations of sm-1.2 on the mitogenic response to a constant concentration of rIGF-II (MSA, 50 $\mathrm{ng} / \mathrm{ml})$, hIGF-II $(50 \mathrm{ng} / \mathrm{ml})$, or insulin $(11 \mu \mathrm{g} / \mathrm{ml})$. Results in the presence of antibody were calculated as a percent of those observed with the same concentration of rIGF-II, hIGF-II, or insulin in the absence of antibody, and the values shown represent the mean \pm SD of those obtained in triplicate specimens in a single experiment. Absolute values for $\left[{ }^{3} \mathrm{H}\right]$ thymidine incorporation (cpm/well; mean $\pm \mathrm{SD}$ ) in the absence of antibody were $207 \pm 61$ in controls and 4,557 \pm 405 in specimens containing rIGF-II $(P<0.001) ; 182 \pm 2$ in controls and $3,202 \pm 373$ in specimens containing hIGF-II $(P<0.001)$; and $117 \pm 62$ in controls and $6,618 \pm 864$ in specimens containing insulin $(P<0.001)$. The results shown are typical of those obtained in six other experiments.

tested, sm-1.2 had no effect on the mitogenic response to insulin (Fig. 4).

In experiments with varying concentrations of rIGF-II and insulin, the independent mitogenic effect of each was confirmed (26). Further, IGF-I did not amplify the effects of these mitogens (data not shown), as it did in the case of TSH (9).

Response to TSH. In what we initially assumed would be negative control studies, we examined the effect of sm-1.2 on the mitogenic response to bTSH. As expected, increasing concentrations of $\mathrm{bTSH}$ produced a dose-dependent stimulation of $\left[{ }^{3} \mathrm{H}\right]$ thymidine incorporation into DNA that, surprisingly, was inhibited by sm-1.2. At a concentration of $10 \mu \mathrm{g} / \mathrm{ml}$, sm-1.2 inhibited the response to $10^{-9} \mathrm{M}$ bTSH by $\sim 50 \%$. Normal mouse IgG had no effect.

Additional studies were conducted in which the effects of varying concentrations of bTSH and sm-1.2, alone and in combination, were assessed concomitantly (Fig. 5). In these experiments, the inhibitory effect of each concentration of antibody was greatest at the lower concentrations of bTSH and least at the higher concentrations of bTSH. Further, for each concentration of bTSH, we observed a concentration of antibody beyond which no further inhibition of the response to bTSH was observed. As a result, in these maximally inhibited specimens, a dose-dependent stimulatory effect of bTSH on $\left[{ }^{3} \mathrm{H}\right]$ thymidine incorporation was preserved.

Ensuing experiments were conducted in an effort to ascertain the mechanism by which the anti-IGF antibody sm-1.2 inhibited the mitogenic responses to bTSH. When added directly to the radioreceptor assay mixture, a concentration of sm-1.2 that strongly inhibited the mitogenic response to high concentrations of bTSH had no effect whatsoever on the binding of tracer concentrations of ${ }^{125}$ I-bTSH (data not shown).

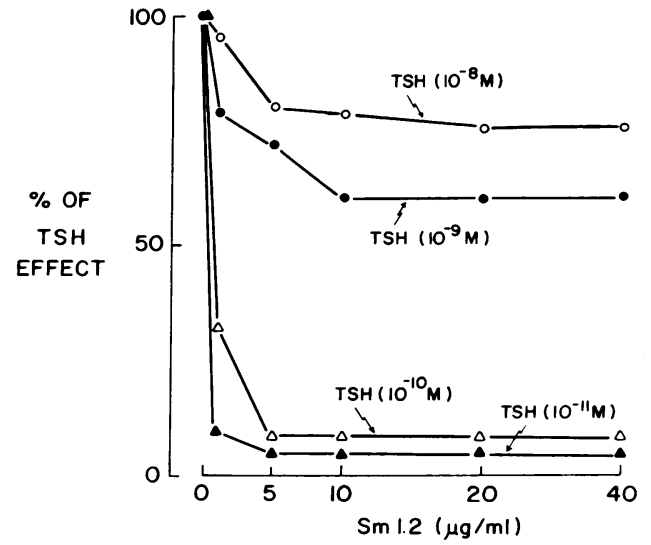

Figure 5. Effects of increasing concentrations of sm-1.2 $(1-40 \mu \mathrm{g} / \mathrm{ml})$ on the mitogenic response to varying concentrations of bTSH $\left(10^{-11}-10^{-8} \mathrm{M}\right)$. The results obtained with each concentration of bTSH in the presence of antibody were calculated as a percent of those obtained with the same concentration of bTSH in the absence of antibody, and the values shown represent the mean \pm SD of those obtained in triplicate specimens in a single experiment. Absolute values for $\left[{ }^{3} \mathrm{H}\right]$ thymidine incorporation (cpm/well) in the absence of antibody were $147 \pm 49$ in controls and $515 \pm 104$ in specimens containing bTSH $10^{-11} \mathrm{M}(P<0.05) ; 254 \pm 131$ in controls and $20,884 \pm 576$ in samples containing bTSH $10^{-10} \mathrm{M}(P<0.001)$; $102 \pm 4$ in controls and $14,193 \pm 215$ in samples containing bTSH $10^{-9} \mathrm{M}(P<0.001) ; 116 \pm 12$ in controls and $18,396 \pm 345$ in samples containing bTSH $10^{-8} \mathrm{M}(P<0.001)$. Closely comparable results were obtained in two other experiments.

Because the stimulation of DNA synthesis that bTSH produces in quiescent FRTL5 cells evidently depends on the increase in cellular cAMP concentration that it produces $(5,6$, 10 ), experiments were conducted to determine whether sm-1.2 would modify this response; however, no alteration of the cAMP response to bTSH by sm-1.2 was observed (data not shown).

Responses to $B t_{2} c A M P$, forskolin, cholera toxin, and Graves'-IgG. Because the mitogenic effect of bTSH in quiescent FRTL5 cells is mimicked by other agents that increase the effective intracellular cAMP concentration (10), we examined the effect of sm-1.2 on the ability of these agents to stimulate $\left[{ }^{3} \mathrm{H}\right]$ thymidine incorporation into DNA. As anticipated, cholera toxin, forskolin, and $\mathrm{Bt}_{2} \mathrm{CAMP}$, tested at their maximally effective concentrations (10), as well as Graves'-IgG (9), were all stimulatory to DNA synthesis, and their effects all were inhibited in a concentration-dependent manner by sm-1.2 (Fig. 6).

Cell replication. Studies were conducted to determine the effects of the anti-IGF antibody sm-1.2 on the stimulation of cell replication induced by bTSH, IGF-I, and insulin (Fig. 7). In four separate observations, cell counts at $5 \mathrm{~d}$ in specimens treated with bTSH were $394 \pm 8.3 \%$ those in control specimens; this increase was significantly diminished $(P<0.001)$ by the addition of sm-1.2, since cell counts in the presence of sm-1.2 were only about double those in controls (Fig. 7). A smaller enhancement of cell replication was produced by IGF-I, which increased cell counts to an average of $148 \pm 6.9 \%$ of those in control wells. As would be expected, the mitogenic response to IGF-I was entirely abolished by sm-1.2, cell counts in the presence of IGF-I and antibody being indistinguishable from those in control wells. 


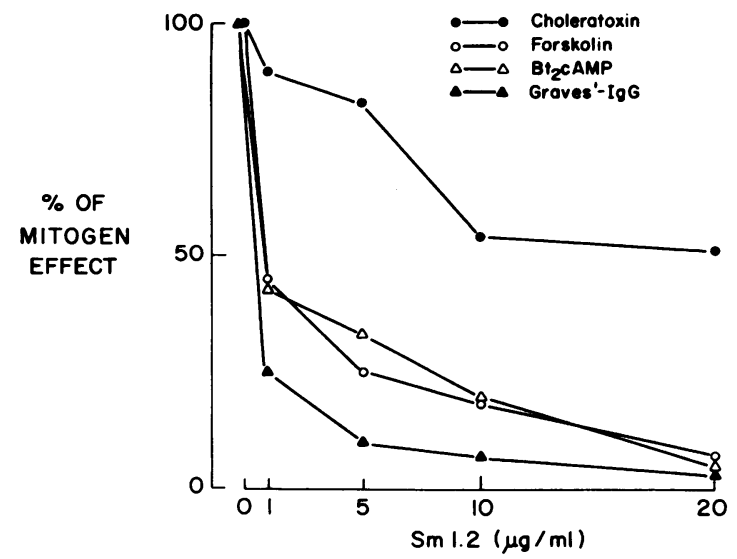

Figure 6. Effects of increasing concentrations of sm-1.2 on the mitogenic responses to cholera toxin $(10 \mathrm{pg} / \mathrm{ml})$, forskolin $\left(10^{-5} \mathrm{M}\right)$, $\operatorname{Bt}_{2}$ CAMP $\left(10^{-4} \mathrm{M}\right)$, and Graves'-IgG $(2 \mathrm{mg} / \mathrm{ml})$. The results for each agent in the presence of antibody were calculated as a percent of those obtained with same concentration of the agent in the absence of antibody, and the values shown represent the mean \pm SD of those obtained in triplicate specimens in a single experiment. Absolute values of $\left[{ }^{3} \mathrm{H}\right]$ thymidine incorporation in the absence of antibody (cpm/well; mean $\pm \mathrm{SD}$ ) were $483 \pm 25$ in controls and $4,734 \pm 160$ in the presence of cholera toxin; $653 \pm 56$ in controls and $12,208 \pm 709$ in the presence of forskolin; $896 \pm 157$ in controls and 7,157 in the presence of $\mathrm{Bt}_{2} \mathrm{CAMP}$; and $306 \pm 136$ in controls and $15,931 \pm 3,825$ in the presence of Graves' IgG. For all differences between control and stimulated values of $\left[{ }^{3} \mathrm{H}\right]$ thymidine incorporation, $P<0.001$. Similar results were obtained in two other experiments.

Only two observations were available concerning the effect of sm-1.2 in insulin-induced cell replication. At the concentration tested, insulin alone caused only a slight $(\sim 30 \%)$ increase in cell counts, and this was unaffected by the further addition of $\mathrm{sm}-1.2$.

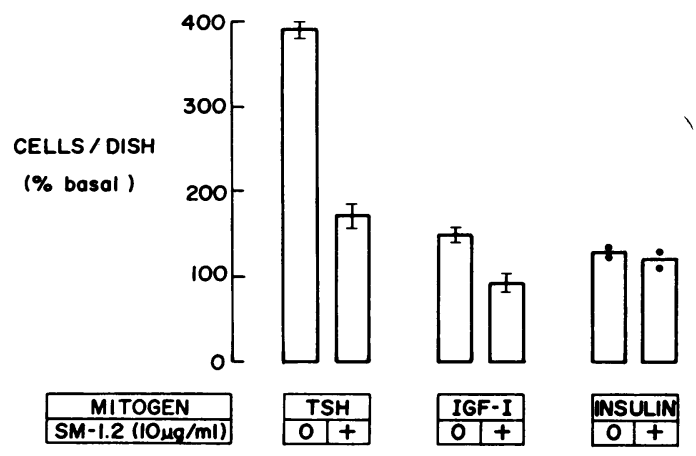

Figure 7. Effect of antibody sm-1.2 $(10 \mu \mathrm{g} / \mathrm{ml})$ on the stimulation of replication in FRTL5 cells induced by bTSH $\left(10^{-10} \mathrm{M}\right)$, IGF-I ( 10 $\mathrm{ng} / \mathrm{ml})$, or insulin $(1 \mu \mathrm{g} / \mathrm{ml})$. Results shown represent the cell number per dish as a percent of that in basal (unstimulated) specimens. Bars represent the means \pm SD of values obtained in four separate observations in the case of TSH and IGF-I. Bars represent the mean of two observations in the case of insulin. Cell numbers in the presence of TSH alone and IGF-I alone are significantly higher than basal values $(P<0.001)$. The reduction in cell numbers induced by sm-1.2 is significant in the case of both bTSH $(P<0.001)$ and IGF-I $(P<0.05)$.
Effects of antibody sm-1.2 in M12 cells

Basal thymidine incorporation into DNA. As a reflection of their ability to replicate in the absence of TSH or other added mitogens, basal rates of $\left[{ }^{3} \mathrm{H}\right]$ thymidine incorporation into the DNA of M12 mutant cells were higher than in FRTL5 cells, averaging $1,417 \pm 472 \mathrm{cpm}(n=3)$. As would be expected if the greater rate of growth of M12 cells was due to their greater secretion of rIGF-II into the culture media, addition of sm-1.2 produced a much greater inhibition of thymidine incorporation than that observed in FRTL5 cells, reducing values of thymidine incorporation in M12 cells by $\sim 90 \%(155 \pm 55)$ from control levels.

Cell replication. M12 mutant cells displayed vigorous growth when cultured in 5\% calf serum in the absence of other specific mitogens. Growth of the cells was severely retarded by the addition of sm-1.2 at a concentration of $10 \mu \mathrm{g} / \mathrm{ml}$ (Fig. 8). In view of the possibility that the effect of sm-1.2 on the replication of M12 cells was due to an inhibition of the effect of IGF-I present in the $5 \%$ calf serum in which they were grown, comparable studies were conducted in M12 cells cultured in Coon's modified Ham's F- 12 medium containing $0.1 \%$ BSA. In this medium, as expected, growth of the M12 cells was less luxuriant, cell number in control dishes increasing by $32 \%$ in 5 $\mathrm{d}$, whereas in the presence of sm-1.2 there was no increase at all.

\section{Discussion}

The central observation that led to the present studies was our finding that, in the FRTL5 line of rat thyroid follicular cells, IGF-I and IGF-II not only exert an independent mitogenic effect, but also greatly amplify the action of bTSH to stimulate DNA synthesis (8). Thus, our later observation that sm-1.2, a monoclonal antibody against both IGF-I and IGF-II, produced a dose-dependent inhibition of the mitogenic effect of bTSH in the absence of added IGF led us to examine whether one or another of the IGFs might be produced by these cells. The resulting studies provide strong evidence, we believe, that IGF-II is synthesized by the FRTL5 cell and secreted into its culture medium, that endogenous IGF-II acts as an autocrine growth factor for the FRTL5 cell, and that it acts to augment the mitogenic response of the FRTL5 cell to TSH, the major regulator of thyroid cell growth in this system.

The major evidence that FRTL5 cells secrete IGF-II is the direct demonstration that within $48 \mathrm{~h}$ of culture FRTL5 cells secrete into their media readily measurable concentrations of a peptide that interacts in a specific RIA for IGF-II, producing therein a displacement curve parallel to that generated by authentic rIGF-II. By the same techniques, production of IGF-I could not be detected.

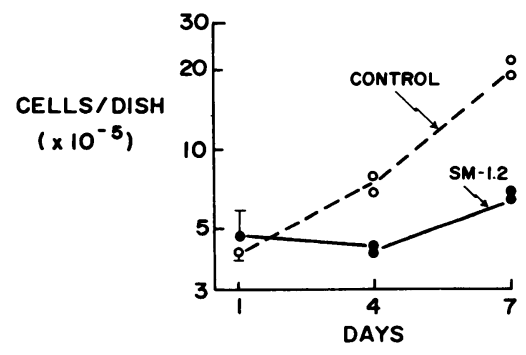

Figure 8. Effect of sm- 1.2 on the replication of M12 cells. Values at $1 \mathrm{~d}$ are the mean \pm SD of those obtained in four separate dishes. Values at 4 and $7 \mathrm{~d}$ represent cell numbers in two separate dishes for each time point. 
Other evidence strongly indicates that the rIGF-II secreted by the FRTL5 cells plays an important role in regulating the growth of FRTL5 cells. It is perhaps not surprising that media conditioned by FRTL5 cells with rIGF-II should both stimulate $\left[{ }^{3} \mathrm{H}\right]$ thymidine incorporation in the absence of TSH and amplify the comparable response to added TSH, since we had already demonstrated similar effects of highly purified exogenous rIGF-II. More significant, therefore, were the observations with the monoclonal anti-IGF antibody sm-1.2. Addition of this antibody to the culture medium permitted us to eliminate and thereby to identify any functional effects of the endogenous IGF-II that the FRTL5 cells were secreting. The principal consequence of adding sm-1.2 to the FRTL5 culture medium that we observed was an inhibition of the stimulatory effect of bTSH on cell replication and $\left[{ }^{3} \mathrm{H}\right]$ thymidine incorporation. The extent of inhibition of $\left[{ }^{3} \mathrm{H}\right]$ thymidine incorporation varied directly with the concentration of $\mathrm{sm}-1.2$ used and inversely with the concentration of bTSH. Further, for each concentration of TSH tested, a concentration of sm-1.2 was evident beyond which addition of further antibody produced no further inhibitory effect. We would suggest that the mitogenic response to each concentration of bTSH observed at these high levels of sm-1.2 represents the intrinsic mitogenic effect of that concentration of bTSH, devoid of any amplifying influence of endogenous rIGF-II. By the same token, we would suggest that, in the FRTL5 cell, amplification of the response to TSH is the principle autocrine effect of endogenous rIGF-II with respect to growth.

It might be assumed that the ability of sm-1.2 to inhibit the mitogenic responses to TSH was the result of other mechanisms, rather than a blockade of endogenous rIGF-II. Several such possibilities were examined directly and excluded. Thus, the antibody did not inhibit either the specific binding of TSH in FRTL5 cells or the increase in CAMP accumulation induced by TSH therein. Further, the possibility that sm-1.2 was in some manner cytotoxic was excluded by the finding that concentrations of antibody highly inhibitory to the response to TSH failed to inhibit the increase in thymidine incorporation or cell replication induced by insulin.

In contrast, sm-1.2 did inhibit the independent mitogenic responses to $\mathrm{Bt}_{2} \mathrm{CAMP}$, forskolin, cholera toxin, and Graves' $\mathrm{IgG}$, all of which increase the effective intracellular cAMP concentration. The effect of these agents, like that of TSH, is amplified by IGF-I and IGF-II $(8,9)$. Therefore, the ability of sm-1.2 to inhibit the response to these agents supports our earlier suggestion that the amplifying interaction between the cAMP-dependent pathway activated by TSH and the cAMPindependent pathway activated by IGF takes place at some post-cAMP site $(9,27)$.

Observations with sm-1.2 may also shed some light on the biology of the M12 mutant cells, which grow vigorously in the absence of TSH. These cells condition their media with concentrations of rIGF-II four to five times higher than those found in media conditioned by FRTL5 cells, and the media conditioned by M12 cells have a more pronounced stimulatory effect on both basal and TSH-stimulated $\left[{ }^{3} \mathrm{H}\right]$ thymidine incorporation in quiescent FRTL5 cells than media conditioned by FRTL5 cells. Moreover, basal thymidine incorporation in these cells, which is substantial as a reflection of their spontaneous growth, is greatly inhibited by the addition of sm-1.2, and cell replication is greatly retarded by the antibody.

These findings raise the possibility that the capacity of M12 mutant cells to grow spontaneously may reflect, at least partly, the high level of rIGF-II that they produce. This is not to suggest, however, that the mutation that makes these cells independent of TSH is one that results solely in enhanced production of IGF-II. Indeed, the nature of the mutation remains uncertain.

There is a clear and increasing precedent for the presence of a variety of autocrine growth factors within different tissues $(28-46)$. With respect to the IGFs, several studies have presented evidence of their release into the medium by cells in tissue culture (28-35). Further, recent studies have provided evidence for the synthesis of IGFs in rat and human tissues, as judged from measurements of tissue concentration and the demonstration of the cellular localization of specific mRNAs by in situ hybridization, respectively (36-46).

A precedent also exists for an endogenous IGF to modify the response to an exogenous growth factor. In studies of porcine aortic smooth muscle cells and human fibroblasts, Clemmons and Van Wyk have found that sm-1.2, the same antiIGF antibody that we used, significantly inhibited both basal thymidine incorporation and the mitogenic response to platelet-derived growth factor (47). These findings led to the suggestion that platelet-derived growth factor-induced mitogenesis in these cell types is due in part to stimulation of the production of an IGF-like peptide. We have no information concerning the extent to which mitogenic agents whose action in FRTL5 cells is cAMP-mediated may exert their effect by increasing the synthesis of the endogenous IGF-II, which then stimulates growth. In all likelihood, however, this is not a major mechanism by which agents like bTSH stimulate growth in FRTL5 cells. First, the persistence of a dose-dependent mitogenic effect of TSH in the presence of increasing amounts of anti-IGF antibody strongly indicates that TSH was exerting an independent mitogenic effect. Second, the increase in $\left[{ }^{3} \mathrm{H}\right]$ thymidine incorporation into DNA in FRTL5 cells induced by the addition of synergistic concentrations of TSH and IGF-I is far in excess of the concomitantly measured response to maximally effective concentrations of IGF-I alone (9).

With respect to the thyroid cell, studies in primary cultures derived from different species, such as the dog, sheep, human, pig, and rat, have shown that growth factors, such as insulin and epidermal growth factor, have an independent stimulatory effect on growth and augment the response to TSH $(1-3,7$, 48-50). However, in none of these instances has it been shown that the cell type that responds to epidermal growth factor or insulin produces either of the two growth factors. Conversely, ours is not the first demonstration of the production of IGF-I by a thyroid cell, since Mak and co-workers have reported synthesis of IGF-I by ovine thyroid cells in primary culture (51). However, these investigators did not provide any evidence that this endogenous IGF-I subserves a significant functional role in the ovine thyroid cell.

The most interesting questions that arise from these findings are whether one or another IGF is produced by the thyroid in the living animal, and if so, whether it acts as a mitogen locally, whether it modifies the response to TSH, and how its production is regulated.

\section{Acknowledgments}

This work was supported in part by grants DK-18416 and DK-37663 from the National Institute of Diabetes and Digestive and Kidney Diseases, Bethesda, MD. 


\section{References}

1. Ambesi-Impiombato, F. S., R. Picone, and D. Tramontano. 1982. Influence of hormones and serum on growth and differentiation of the thyroid cell strain FRTL. In Growth of Cells in Hormonally Defined Media. D. A. Sirbasku, G. H. Sato, and A. Pardee, editors. Cold Spring Harbor Laboratory, Cold Spring Harbor, NY. 483-492.

2. Roger, P. O., and J. E. Dumont. 1984. Factors controlling proliferation and differentiation of canine thyroid cells cultured in reduced serum conditions: effect of thyrotropin and growth factors. Mol. Cell. Endocrinol. 36:79-93.

3. Gartner, L., W. Greil, R. Demharter, and K. Horn. 1985. Involvement of cyclic AMP, iodide and metabolites of arachidonic acid in the regulation of cell proliferation of isolated porcine thyroid follicles. Mol. Cell. Endocrinol. 42:145-155.

4. Dere, W. H., H. Hirayu, and B. Rapoport. 1985. TSH and cAMP enhance expression of the myc proto-oncogene in cultured thyroid cells. Endocrinology. 117:2249-2251.

5. Tramontano, D., W. W. Chin, A. C. Moses, and S. H. Ingbar. 1986. Thyrotropin and dibutyryl cyclic AMP increase levels of c-myc and c-fos mRNAs in cultured rat thyroid cells. J. Biol. Chem. 261:3919-3922.

6. Jin, S., F. J. Norniceck, D. Meylan, M. Zakarija, and J. M. McKenzie. 1986. Evidence that adenosine 3',5'-monophosphate mediates stimulation of thyroid growth in FRTL5 cells. Endocrinology. 119:802-810.

7. Errick, J. A., K. W. A. Ing, M. C. Eggo, and G. N. Burrow. 1986. Growth and differentiation in cultured human thyroid cells: effects of epidermal growth factor and thyrotropin. In Vitro Cell. Dev. Biol. 22:28-36.

8. Tramontano, D., G. W. Cushing, A. C. Moses, and S. H. Ingbar. 1986. Insulin-like growth factor-I stimulates the growth of rat thyroid cells in culture and synergizes the stimulation of DNA synthesis induced by TSH and Graves'-IgG. Endocrinology. 119:940-942.

9. Tramontano, D., A. C. Moses, B. M. Veneziani, and S. H. Ingbar. 1988. Adenosine $3^{\prime}, 5^{\prime}$-monophosphate mediates both the mitogenic effect of TSH and its ability to amplify the responses to insulin-like growth factor-I in FRTL5 cells. Endocrinology. 122:127-132.

10. Maciel, R. M. B., A. C. Moses, D. Tramontano, and S. H. Ingbar. 1987. Evidence that insulin-like growth factor-I is an autocrine growth factor that synergizes cAMP-mediated growth in FRTL5 cells. Prog. 62nd Annu. Meet. Am. Thyroid Assoc. T-60. (Abstr.)

11. Russell, W. E., J. J. Van Wyk, and W. J. Pledger. 1984. Inhibition of the mitogenic effects of plasma by a monoclonal antibody to somatomedin C. Proc. Natl. Acad. Sci. USA. 81:2389-2392.

12. Furlanetto, R. W. 1982. Pitfalls in the somatomedin-C radioimmunoassay. J. Clin. Endocrinol. Metab. 54:1084-1086.

13. Furlanetto, R. W., L. E. Underwood, J. J. Van Wyk, and A. J. D'Ercole. 1977. Estimation of somatomedin-C levels in normals and patients with pituitary disease by radioimmunoassay. J. Clin. Invest. 60:648-657.

14. Moses, A. C., S. P. Nissley, J. Passamani, R. White, and M. M. Rechler. 1980. Immunological cross-reactivity of multiplication stimulating activity (MSA) polypeptides. Eur. J. Biochem. 103:401-408.

15. Greenstein, L. A., S. P. Nissley, A. C. Moses, P. A. Short, YW-H. Yang, L. Lee, and M. M. Rechler. 1984. Purification of multiplication-stimulating activity. In Methods for Preparation of Media, Supplements, and Substrata for Serum-free Animal Cell Culture. G. Sato and D. Barnes, editors. Alan R. Liss, Inc., New York. 111-138.

16. Rinderknecht, T., and R. E. Humbel. 1978. Primary structure of human insulin-like growth factor II. FEBS. (Fed. Eur. Biochem. Soc.) Lett. 89:283-286.

17. Tramontano, D., C. M. Rotella, R. Toccafondi, and F. S. Ambesi-Impiombato. 1986. Thyrotropin-independent mutant clones from FRTL5 rat thyroid cells: hormonal control mechanisms in differentiated cells. Endocrinology. 118:862-868.

18. Moses, A. C., S. P. Nissley, J. Passamani, R. White, and M. M. Rechler. 1977. Further characterization of a GH-dependent somatomedin binding protein in rat serum and demonstration of a somato- medin binding protein produced by rat liver cells in culture. Endocrinology. 104:536-546.

19. Koistinen, R., N. Kalkkinen, M. L. Huhtala, M. Seppala, H. B. Rutanen, and E.-M. Rutanen. 1986. Placental Protein 12 is a decidual protein that binds somatomedin and has an identical $\mathrm{N}$-terminal amino acid sequence with somatomedin-binding protein from human amniotic fluid. Endocrinology. 118:1375-1378.

20. Hsu, C. J., and J. M. Hammond. 1987. Gonadotropins and estradiol stimulate immunoreactive insulin-like growth factor-I production by porcine granulosa cells in vitro. Endocrinology. 120:198207.

21. Pilistine, S. J., A. C. Moses, and H. N. Munro. 1984. Insulinlike growth factor receptors in rat placental membranes. Endocrinology. 115:1060-1065.

22. Mitchell, M. L., R. J. Hermos, and A. C. Moses. 1987. Radioimmunoassay of somatomedin-C on filter paper discs containing dried blood. Clin. Chem. 33:536-538.

23. Tramontano, D., and S. H. Ingbar. 1986. Properties and regulation of the TSH receptor in the FRTL5 rat thyroid cell line. Endocrinology. 118:1945-1951.

24. Goldfine, I. D., S. H. Amir, A. W. Peterson, and S. H. Ingbar. 1974. Preparation of biologically active ${ }^{125}$ I-TSH. Endocrinology. 95:1228-1233.

25. Zar, J. H. 1974. Multiple comparisons. In Biostatistical Analysis. Prentice-Hall, Englewood Cliffs, NJ. 151.

26. Tramontano, D., A. C. Moses, R. Picone, and S. H. Ingbar. 1987. Characterization of the receptor for insulin-like growth factor-I (IGF-I) in the FRTL5 rat thyroid follicular cell line. Endocrinology. 120:785-790.

27. Zederman, R., C. Greenburg, K. Hall, and H. Low. 1980. Effect of somatomedin-C and insulin on cyclic AMP generation in isolated rat hepatocytes. Horm. Metab. Res. 12:251-256.

28. Clemmons, D. R., L. E. Underwood, and J. J. Van Wyk. 1981. Hormonal control of immunoreactive somatomedin production by cultured human fibroblasts. J. Clin. Invest. 67:10-19.

29. Atkison, P. R., E. R. Weidman, B. Bhaumick, and R. M. Bala. 1980. Release of somatomedin-like activity by cultured W1-38 human fibroblasts. Endocrinology. 106:2006-2012.

30. Adams, S. O., S. P. Nissley, S. Handwerger, and M. M. Rechler. 1983. Developmental patterns of insulin-like growth factor-I and -II synthesis and regulation in rat fibroblasts. Nature (Lond.). 302:150153.

31. D'Ercole, A. J., G. T. Applewhite, and L. E. Underwood. 1980. Evidence that somatomedin is synthesized by multiple tissues in the fetus. Dev. Biol. 75:315-328.

32. Clemmons, D. R. 1985. Variables controlling the secretion of a somatomedin-like peptide by cultured porcine smooth muscle cells. Circ. Res. 56:418-426.

33. Hammond, J. M., J. L. S. Baranao, D. Skaleris, A. B. Knight, J. A. Romanus, and M. M. Rechler. 1985. Production of insulin-like growth factors by ovarian granulosa cells. Endocrinology. 117:25532555.

34. Tres, L. L., E. P. Smith, J. J. Van Wyk, and A. L. Kierszenbaum. 1986. Immunoreactive sites and accumulation of somatomedin-C in rat Sertoli-spermatogenic cell co-cultures. Exp. Cell Res. 162:33-50.

35. Smith, E. P., M. E. Svoboda, J. J. Van Wyk, A. L. Kierszenbaum, and L. L. Tres. 1987. Partial characterization of a somatomedin-like peptide from the medium of cultured rat Sertoli cells. Endocrinology. 120:186-193.

36. D'Ercole, A. J., A. D. Stiles, and L. E. Underwood. 1984. Tissue concentration of somatomedin-C: further evidence for multiple sites of synthesis and paracrine or autocrine mechanisms of action. Proc. Natl. Acad. Sci. USA. 81:935-939.

37. Handelsman, D. J., J. A. Spaliviero, C. D. Scott, and R. C. Baxter. 1985. Identification of insulin-like growth factor-I and its receptor in rat testis. Acta Endocrinol. 109:543-549.

38. Stiles, A. D., I. R. S. Sosenko, A. J. D’Ercole, and B. T. Smith. 1985. Relation of kidney tissue somatomedin-C/insulin-like growth 
factor-I to postnephrectomy renal growth in the rat. Endocrinology. 117:2397-2401.

39. Brown, A. L., D. E. Graham, S. P. Nissley, D. J. Hill, A. J. Strain, and M. M. Rechler. 1986. Developmental regulation of insulin-like growth factor II mRNA in different rat tissues. J. Biol. Chem. 261:13144-13150.

40. Lund, P. K., B. M. Moats-Staats, M. A. Hynes, J. G. Simmons, M. Jansen, A. J. D'Ercole, and J. J. Van Wyk. 1986. Somatomedin-C/ insulin-like growth factor-I and insulin-like growth factor-II mRNAs in rat fetal and adult tissues. J. Biol. Chem. 261:14539-14544.

41. Matthews, L. S., G. Norstedt, and R. D. Palmiter. 1986. Regulation of insulin-like growth factor-I gene expression by growth hormone. Proc. Natl. Acad. Sci. USA. 83:9343-9347.

42. Han, V. K. M., A. J. D'Ercole, and P. K. Lund. 1987. Cellular localization of somatomedin (insulin-like growth factor) messenger RNA in the human fetus. Science (Wash. DC). 236:193-197.

43. Hill, D. J., A. Frazer, I. Sweene, P. K. Wirdnam, and R. D. G. Milner. 1987. Somatomedin-C in human fetal pancreas: cellular localization and release during organ culture. Diabetes. 36:465-471.

44. Murphy, L. J., G. I. Bill, and H. G. Friesen. 1987. Tissue distribution of insulin-like growth factor-I and II messenger RNA in the adult rat. Endocrinology. 120:1279-1282.

45. Stylianopoulov, F., J. Herbert, M. B. Soares, and A. Efstratiadis. 1988. Expression of the insulin-like growth factor II gene in the choroid plexus and the leptomeninges of the adult rat central nervous system. Proc. Natl. Acad. Sci. USA. 85:141-145.

46. Rotwein, P., S. K. Burgess, J. D. Milbrandt, and J. E. Krause. 1988. Differential expression of insulin-like growth factor genes in rat nervous system. Proc. Natl. Acad. Sci. USA. 85:265-269.

47. Clemmons, D. R., and J. J. Van Wyk. 1985. Evidence for a functional role of endogenously produced somatomedin-like peptides in the regulation of DNA synthesis in cultured human fibroblasts and porcine smooth muscle cells. J. Clin. Invest. 75:1914-1918.

48. Smith, P., D. Wynford-Thomas, B. M. J. Stringer, and E. D. Williams. 1986. Growth factor control of rat thyroid follicular cell proliferation. Endocrinology. 119:1439-1445.

49. Westermark, K., and B. Westermark. 1982. Mitogenic effect of epidermal growth factor on sheep thyroid cells in culture. Exp. Cell Res. 138:47-55.

50. Roger, P. P., P. Servais, and J. E. Dumont. 1983. Stimulation by thyrotropin and cyclic AMP of the proliferation of quiescent canine thyroid cells cultured in a defined medium containing insulin. FEBS. (Fed. Eur. Biochem. Soc.) Lett. 157:323-329.

51. Mak, W. W.-N., M. D. Eggo, and G. N. Burrow. 1985. Characterization of proteins secreted by primary cultures of ovine thyroid cells. In Thyroglobulin: The Prothyroid Hormone. M. C. Eggo and G. N. Burrow, editors. Raven Press, New York. 243-254. 